the flints were fixed in such a manner that a moving mass of ice or earth slipped over, scratching the upper face and 'retouching' the opposite.

"One can often see that the predominating direction of the scratches is almost normal at the chipped edges. Sometimes it is evident that the hard substance which has incised a deep scratch has also dug, in some place where its action has been prolonged, a little 'cupola of contusion'. Later the line was continued as far as the more fragile edge, where the flint breaks, giving a bunch of chips on the other side, thus simulating a concave scraper.

"These explanations account for most of the so-called 'worked flints' of Pre-Crag beds and are very like those which you proposed. But it is astonishing that to obtain a good type of 'rostro-carinate' or similar 'implements' so many renewals of chipping of very different ages were necessary.

"So it seems some of the chipped facets can be Eocene, and the continuation of the same working could be Miocene or Pliocene. In any case, the difference of the age between the successive chippings is so great that it excludes the probability of the work of man. Otherwise very different actions seem to have collaborated. Probably in the first bedding of these flints there was the same compression as at Boncelles and Belle Assise; afterwards they were transported by diverse forces (more or less violent) which have left sometimes traces extremely energetic. Others, specially, more or less deeply graven lines, generally limited to one side, are to be considered. Often the other side is similarly favoured by abundant 'retouching'.

"I believe it is necessary to exercise very great caution and possess much familiarity with both 'natural' and 'artificial' chipping of flint to enable one to distinguish the difference. In many cases the natural fracture gives the same appearance as the rough working and chipping of Man. So it is sometimes impossible to distinguish between the work of Nature or Man, and the proof will come from another source than the morphology, which is too deceitful, because the natural inclination of the human imagination is towards the 'morphomanic'.

"As to the Ipswich skeleton, I think that it is senseless to present it as 'Pre-Glacial'. The superdeposited soil is evidently due to the alteration and transport of Boulder-clay down the slope. It is not Boulder-clay, it is a dateless deposit (limon). The body had the position of a buried person, fairly old, perhaps Neolithic. A grave dug in non-stratified soil would not have left any trace after a considerable time. The decalcified soil of the clay and of the grave ('|Middle Glacial ') would not bave permitted the preservation of a body so old at such a sballow depth.

"Finally, the position of the body is absurd. If the body had been abandoned on the seashore it would have been dismembered, and the bones would have been separated, rolled, destroyed. If the body is later than this marine plateau (and it is, since it is partly in the overlying bed), then it dates from this later bed; but if so, if it was a ' moraine de fond', the man could not have been precipitated into it, neither dead nor alive, and a body on the shore of the Middle Glacial sands would have suffered terrible injuries from the glacier. The bones would have been crushed, disjointed, and dissolved by the waters of the glacier.

"All this is incomprehensible on the hypothesis of Mr. Moir, and, on the contrary, is amply explained by yours and mine-burial in date probably late prehistoric, in a modern soil derived by means of the alteration and the reshuffling of the chalky Boulder-clay.

\title{
THE ALKALINE ROCKS OF SOUTH-WEST AFRICA.
}

SIR,-Since reading Mr. Holmes' paper on the alkaline rocks of Angola (Groc. Mag., July and August, 1915) I have thought that a brief note on the somewhat similar rocks occurring near Pomona and in Namaqualand may be of immediate interest. I received a collection of these rocks from Dr. A. W. Rogers in 1914 , and $I$ intend to visit 
the localities myself to make a fuller study than is possible in the laboratory. In the meantime the following notes may be of interest. The nephelite-syenite of the Granitberg was described very briefly by Wagner. It is a foyaite with a very variable amount of nephelite, which may locally make up two-thirds of the rock. 'The chief dark mineral is a green ægirite-augite. This rock is cut by two dykes of a singularly interesting microfoyaite which contains, in addition to microperthite, nephelite, and pyroxene, smaller amounts of biotite, perovskite, and zircon. The perovskite forms perfect octahedrons up to half a millimetre in diameter. Zircon occurs in skeletons and irregular groups and plates, and often encloses grains and laths of felspar. The dark minerals amount to just under 10 per cent of the rock.

From the neighbourhood of Pomona there are several monchiquites and camptonites, some fresh and others too much decomposed for certain identification. In one of the camptonites, crystals of barkevikite are enclosed by titanaugite with a reaction rim of magnetite separating the two. In all these lamprophyres there are pseudomorphs of a mineral like iddingsite, apparently replacing olivine. I have also a beautiful ægirite-solvsbergite with marked flow-structure, and some typical bostonites and lindöites. Dr. Rogers has also.found numerous bostonite dykes in Van Rhyn's Dorp and Namaqualand.

I hope to publish a full account of these interesting rocks in the course of time.

Geology Department, Victoria College,

S. J. Shand. STELLENBosCH, S.A.

October 1, 1915.

BURSTING OF A LAKE BARRIER IN ARGENTINA.

SrR,- It is not often that one finds anything of geological interest in the report of a railway company, but the following details from the Report of the Directors of the Buenos Ayres Great Southern Railway Company for the year ended June 30,1915 , are interesting.

"The most sensational, although by no means the most costly, of the long series of mishaps due to this cause [the weather], was the cataclysm in the Rio Colorado Valley in the early days of January, when some thirty-six miles of the Railway were submerged under deep water, and traffic on the Neuquen line beyond Gavietas was entirely cut off for almost a month. This stupendous, and at first inexplicable visitation, was discovered to be the outcome of the sudden release, 350 miles away from the line as the crow flies, of an immense body of water called Lake Carrilauquen, which had been formed by a landslide at a comparatively recent geological epoch. Owing to stress of weather this natural dam suddenly gave was and thus launched 2,800,000,000 tons of water into the valley of the Rio Colorado."

The lake is nearly 6,000 feet above the sea-level. It was some 15 miles long, $1 \frac{1}{4}$ miles wide, and over 300 feet deep at the lower end.

Bernakd Hobson. 